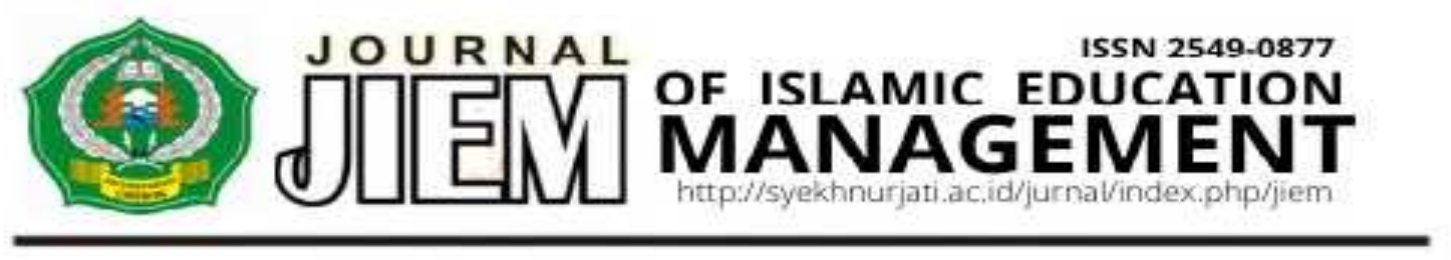

\title{
STRATEGI KEPALA SEKOLAH DALAM MENGEMBANGKAN SARANA PENDIDIKAN DI MTS NEGERI 2 KOTA CIREBON THE PRINCIPAL'S STRATEGY IN DEVELOPING EDUCATIONAL FACILITIES IN MTS NEGERI 2 CITY CIREBON
}

\author{
Nur Aliffah, Taqiyuddin, Mumun Munawaroh, Iim Fatihah \\ Institut Agama Islam Negeri (IAIN) Syekh Nurjati Cirebon \\ nuraliffah_Std@syekhnurjati.ac.id, taqiyuddin@syekhnurjati.ac.id, \\ mumun@syekhnurjati.ac,id, iimfatihah@syekhnurjati.ac.d
}

\begin{abstract}
The problem of educational facilities is basically complex. Schools are required to have independence to regulate and manage the interest of the school. According to their own needs and abilities and based on quality, aspirations and participation of school resident continue to refer to applicable national education laws and regulations. The principal as a leader plays an important role in managing the facilities at the school in order to support his learning activities at school. For this reason this research was conducted, explaining the importance of the participal's role and the principal's strategy in developing educational facilities. This research in based on the SISDIKNAS law and corcerned theory. Research approach using qualitative research. Data collection techniques though participant observation, in-depth interviews and documentations. Technical analysis of qualitative data through data reduction, data presentation and conclusion drawing. Based on the results of the research that : 1) The principal has done his part in developing education facilities in MTs Negeri 2 Cirebon City.

2) The strategy under taken by school principals in developing educational facilities is by forming special taems, collaborations with other institutions or againcies. 3) The inhibiting factor for school principals in developing educational facilities is the length of disbursement of funds from the goverment, while supporting factors for school principals in developing educational facilities is the incomplete facilities available in schools to support learning activities.
\end{abstract}

Keywords: Strategy, Principal, Education facilities.

\begin{abstract}
ABSTRAK
Masalah sarana pendidikan pada dasarnya cukup kompleks. Sekolah dituntut memiliki kemandirian untuk mengatur dan mengurus kepentingan sekolah menurut kebutuhan dan kemampuan sendiri serta berdasarkan mutu, aspirasi dan partisipasi warga sekolah tetap mengacu pada peraturan dan perundang-
\end{abstract}


undangan pendidikan nasional yang berlaku. Kepala sekolah sebagai pemimpin, berperan penting dalam mengelola sarana yang terdapat disekolah demi menunjangnya kegiatan pembelajaran disekolah.Untuk itulah penelitian ini dilakukan, memaparkan pentingnya peran kepala sekolah dan strategi kepala sekolah dalam mengembangkan sarana pendidikan. Penelitian ini didasarkan pada 
undang-undang sisdiknas dan teori prihatin. Pendekatan penelitian menggunakan penelitian kualitatif. Teknik pengumpulan data melalui obserfasi partisipan, wawancara mendalam dan dokumentasi. Teknis analisi data kualitatif melalui reduksi data, penyajian data dan penarikan kesimpulan. Berdasarkan hasil penelitian bahwa: 1) kepala sekolah sudah melakukan peranannya dalam mengembangkan sarana pendidikan di MTs Negeri 2 Kota Cirebon. 2) Strategi yang dilakukan kepala sekolah dalam mengembangkan sarana pendidikan yaitu dengan cara membentuk tim khusus, kerjasama dengan komite sekolah, dan kerjasama dengan lembaga atau instansi lain. 3) Faktor penghambat kepala sekolah dalam mengembangkan sarana pendidikan yaitu lamanya pencairan dana dari pemerintah, sedangkan faktor pendukung kepala sekolah dalam mengembangkan sarana pendidikan yaitu belum lengkapnya fasilitas yang terdapat disekolah untuk menunjang kegiatan pembelajaran.

Kata Kunci: Strategi, Kepala Sekolah, Sarana Pendidikan.

A. PENDAhUluan

Pendidikan adalah
usaha yang dilakukan baik
secara sadar maupun tidak sadar
yang dengan sengaja dirancang
untuk mencapai tujuan yang
telah ditetapkan ran
mengandung pembinaan
kepribadian. Pendidikan juga
bertujuan untuk meningkatkan
kualitas sumber daya manusia.
Salah satu cara yang dilakukan
dalam meningkatkan kualitas
pendidikan melalui proses
belajar mengajar ratau
pembelajaran. Pembelajaran bisa
dilaksanakan baik secara formal
maupun nonformal, baik melalui
sekolah maupun luar sekolah,
sehingga diharapkan seluruh
komponen bangsa Indonesia bisa
mengenyam pendidikan sebagai
kebutuhan utama masyarakat
sebagiamana tercantum dalam
undang-undang dasar 1945
dalam pasal 1 ayat 1 yang
berbunyi "setiap warga negara
berhak anendapatkan
pendidikan".

Kepala madrasah merupakan salah satu komponen pendidikan yang paling berperan dalam meningkatkan kualitas pendidikan.Setiap kepala madrasah memiliki tanggung jawab penuh terhadap seluruh aspek operasional penyelengaraan sekolah, mulai dari perencanaan, pengorganisasian, pelaksanaan, sampai pada pengawasan. Guna menjalankan tugasnya tersebut, kepala sekolah wajib memiliki kompetensi kepribadian, manajerial, kewirausahaan, supervisi, dan sosial (Permendiknas nomor 13 tahun 2007).

Kepala madrasah
memiliki sejumlah tugas dan
tanggung jawab yang cukup
berat terutama dalam mengelola
sarana dan prasarana sekolah.
Beberapa tahun terakhir ini
masih sering ditemukan
banyaknya sarana dan prasarana
pendidikan yang dimiliki oleh
sekolah yang diterima sebagai
bantuan, baik dari pemerintah


maupun dari masyarakat yang penggunaannya tidak optimal dan bahkan tidak dapat lagi digunakan sesuai dengan fungsinya. Penyebab hal tersebut terjadi antara lain karena kurangnya kepedulian terhadap sarana dan prasarana yang dimiliki serta tidak adanya pengelolaan yang memadai.

Peningkatan,

pengembangan dan perbaikan pendidikan harus dilakukan secara bertahap dan berkelanjutan. Pengadaan fasilitas di sekolah seperti sarana dan prasarana pendidikan tidak bisa diabaikan dalam proses pendidikan, khususnya dalam kegiatan pembelajaran (Ismaya, 2015:126). Dalam pembaharuan pendidikan tentu saja fasilitas merupakan hal yang dapat mempengaruhi kelangsungan rencana yang telah ditetapkan. Tanpa adanya rencana bisa dipastikan pendidikan tidak akan berjalan dengan lancar. Oleh karena itu jika dalam menerapkan suatu rencana pendidikan maka sarana dan prasarana harus diperhatikan.

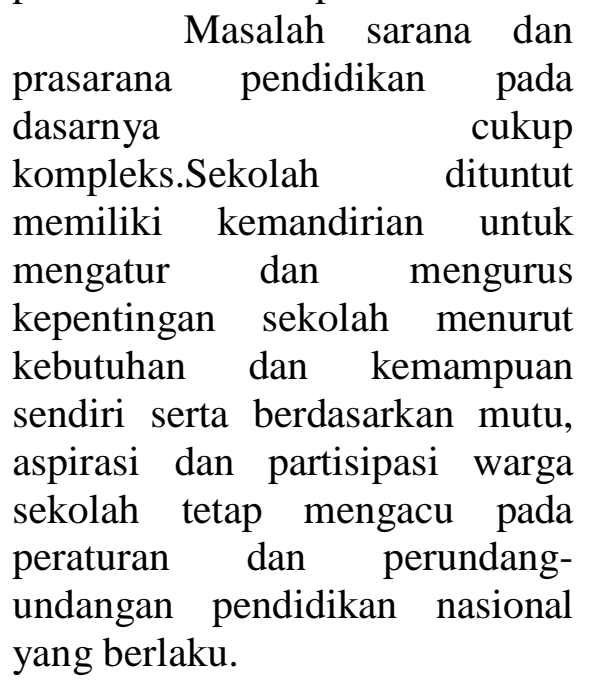

Standar sarana dan prasarana merupakan kebutuhan utama sekolah yang harus terpenuhi sesuai dengan amanat Undang-Undang Sistem Pendidikan Nasional No. 20 tahun 2003, PP No 19 tahun 2005, dan Peraturan Menteri Pendidikan Nasional No. 24 tahun 2007. Selain itu juga, harus memenuhi dari ketentuan pembakuan sarana dan prasarana pendidikan yang telah dijabarkan dalam(1) Keputusan Mendiknas Nomor 129a/U/2004

Tentang Standar Pelayanan Minimal Bidang Pendidikan; (2) Pembakuan Bagunan dan Perabot Sekolah Menengah Pertama Tahun 2004 dari Direktorat Pembinaan SMP/MTS; (3) Panduan Pelaksanaan dan Panduan Teknis Program Subsidi Imbal Swadaya: Pembagunan Ruang Laboratorium Sekolah tahun 2007 dari Direktorat Pembinaan SMP/MTS. Standar Sarana dan prasarana pendidikan yang dimaksud di sini baik mengenai jumlah, jenis, volume, luasan, dan lain-lain sesuai dengan kategori atau tipe sekolahnya masing-masing.

Dalam menjalankan peran dan fungsinya sebagai manajer sarana dan prasarana, kepala madrasah mengelola semua yang terdapat di madrasah yang meliputi gedung, taman, dan peralatan yang lebih berguna bagi sekolah. Segala sesuatu yang ada di sekolah sebisa mungkin dimanfaatkan sebagai pelayanan yang menunjang proses belajar 
mengajar. Kepala madrasah menentukan kelancaran jalannya administrasi di madrasah, karena apabila kepala madrasah mempunyai peranan yang sangat penting sebagai pemimpin di madrasah, kepala madrasah diharapkan mampu memelihara ketertiban sekolah.

Kepala sekolah

dituntut memiliki kreativitas dalam hal pengelolaan sarana dan prasarana yaitu kemauan dan kemampuan dalam menggunakan, mengembangkan, memberdayakan, memelihara, serta mengawasi, sehingga melalui sarana dan prasarana yang ada diharapkan akan mampu memberi dukungan yang sangat kuat di dalam mewujudkan tercapainya tujuan pendidikan di sekolah itu.

Menurut Prihatin

(2011: 58), dalam mengelola sarana dan prasarana sekolah meliputi perencanaan, pengadaan, inventarisasi, pemeliharaan, penggunaan, penghapusan. Jika keenam aspek pengelolaan sarana dan prasarana tersebut tidak dilaksanakan dengan baik, maka akan mendapatkan resiko berupa tidak berdaya gunanya sarana dan prasarana secara optimal. Resiko tersebut berupa kurangnya ketersediaan sarana dan prasarana baik secara kualitas dan kuantitas, banyak sarana prasarana yang rusak dan hilang, serta tidak optimalnya penggunaan sarana prasarana sekolah yang dimiliki sehingga akan memudar daya gunanya begitu saja. Guna mengantisipasi hal tersebut, maka dalam pelaksanaan kegiatan manajemen ini bagian yang paling penting dan berperan aktif adalah kepala sekolah sebagai pengelola pendidikan, kemampuan dalam mengelola sarana prasarana sekolah tersebut guna mewujudkan layanan pembelajaran yang berkualitas. Setelah melakukan observasi awal di MTs Negeri 2 Kota Cirebon pada tanggal 8 Desember $2018 \quad$ melalui wawancara secara langsung dengan wakil kepala sekolah (wakasek) bidang sarana dan prasarana yaitu bapak Didin Jaenudin, S.Pd diperoleh informasi bahwa programprogram pengembangan sarana pendidikan di MTs Negeri 2 Kota Cirebon secara tertulis belum ada. Adapun kendala yang dihadapi sekolah dalam mengembangkan sarana pendidikan adalah keterbatasan anggaran dari pemerintah. Sebab dana yang diperoleh hanya berasal dari dana Bantuan Operasional Sekolah (BOS). Pihak sekolah tidak melakukan kerjasama dengan pihak luar untuk memperoleh bantuan dana.

$\begin{array}{ccr}\text { Kendala } & \text { berikutnya } \\ \text { yaitu } & \text { kesulitan } & \text { dalam }\end{array}$
menentukan penggunaan media pembelajaran antara kelas yang satu dengan kelas yang lain, sering terjadinya perebutan media pembelajaran antara guru yang satu dengan guru yang lain, sulit membedakan antara sarana milik sekolah dengan sarana 
yang berasal dari pemerintah. Hal ini menyulitkan pihak MTs dalam kegitan pembelajaran menggunakan media serta kesulitan dalam menghadapi akreditasi. Masalah lainnya adalah seringkali adanya hambatan dalam proses mencairkan bantuan dari pemerintah.

Masalah lainnya perbedaan pendapat atau konflik antara kepala madrasah, wakil kepala madrasah bidang sarana prasarana, dan guru-guru MTs Negeri 2 Kota Cirebon, sehingga sangat sulit untuk mencapai untuk mencapai kesepakatan antara kepala sekolah dengan pihak yang lainnya terkait pengambilan keputusan penting untuk pengembangan sarana dan prasarana.

Dalam penelitian ini, dapat dikemukakan beberapa pertanyaan yang menyangkut permasalahan penelitian, antara lain yaitu:

1. Bagaimana peran kepala madrasah dalam mengembangkan sarana pendidikan di MTs Negeri 2 Kota Cirebon?

2. Strategi apa yang dilakukan kepala madrasah dalam mengembangkan sarana pendidikan di MTs Negeri 2 Kota Cirebon?

3. Apa yang menjadi faktorfaktor penghambat dan pendukung kepala madrasah dalam mengembangkan sarana pendidikan di MTs Negeri 2 Kota Cirebon?

\section{B. METODE}

Dalam penelitian ini, penelitian yang digunakan dalam penelitian ini adalah penelitian lapangan (field research) yang berusaha secara maksimal mengungkap fakta lapangan secara kualitatif empiris melalui metode ilmiah dengan teknik pengumpulan data deskriptif maupun analisis data yang jelas mengenai strategi kepala sekolah dalam mengembangkan sarana pendidikan di MTs Negeri 2 Kota Cirebon.

Tempat dan waktu penelitian ini di laksanakan di MTs Negeri 2 Kota Cirebon yang beralamat di Jalan Kedung Menjangan Desa Kalijaga RT/RW 04/06 Kecamatan Harjamukti Kota Cirebon. Dengan alasan karena terdapat permasalahan yang harus diteliti dan dituntaskan mengenai strategi kepala madrasah dalam mengembangkan sarana pendidikan di MTs Negeri 2 Kota Cirebon. penelitian ini dilaksanakan selama 4 (empat) bulan yang di mulai pada 1 Maret 2019 sampai dengan 30 Juni 2019.

Dalam penetapan sumber peneliti menggunakan 2 sumber yakni sumber praktis dan sumber teoritis. Sumber praktis yaitu sumber yang diperoleh oleh peneliti yang berasal dari lapangan secara langsung dengan segenap kemampuan panca indera (Kurniawan 2016 : 142). Dalam menggunakan sumber praktis peneliti memilih kepala madrsah, wakil kepala madrasah, kepala tata usaha, guru, dan siswa untuk di jadikan 
sumber praktis stsu sumber yang diperoleh dari lapangan oleh peneliti. Sumber teoritis merupakan sumber yang berasal dari teori-teori, baik untuk menyamakan teori, menguggurkan teori ataupun menambahkan teori (Kurniawan 2016:143). Dalam sumber teoritis peneliti menggunakan buku, jurnal ilmiah, dan majalah yang sebanding atau selaras dengan penelitian yang dibuat oleh peneliti.

Teknik pengumpulan data yang digunakan dalam penelitian ini yaitu: 1) Observasi partisipan, Menurut Sugiono (2017: 106), observasi partisipatif atau partisipan ialah peneliti terlibat dalam kegiatan sehari-hari orang yang sedang diamati atau yang digunakan sebagai sumber data penelitian. Dengan melakukan observasi partisipan, maka data yang akan diperoleh peneliti akan lebih lengkap, tajam dan sampai mengetahui pada tingkat makna dan setiap perilaku yang nampak. 2) Wawancara mendalam, Menurut Esterberg (2002) dalam Sugiono (2017: 114) "interviewing is at heart of social research. If you look through research almost any sociological journal, you will find that much social research is based on interview, eighter standardized or more in depth". Interview merupakan harinya peneliti sosial, maka anda temui semua penelitian sosial didasarkan pada interview, baik yang standard maupun yang mendalam. 3) Dokumentasi,
Menurut Sugiyono (2017:114) mengemukakan bahwa dokumentasi merupakan data atau peristiwa yang sudah berlalu. Sedangkan menurut Kurniawan (2017:135) menyatakan bahwa dokumentasi adalah data yang berupa catatan tertulis, tercetak, atau pindai dengan optik. Dengan bahasa lain untuk data yang sifatnya benda mati.

Adapun beberapa tahapan-tahapan dalam analisis data dalam penelitan ini. Menurut Kurniawan (2017 : 153) pada penelitian kualitatif, proses analisis data itu dilakukan dengan tahapan pengumpulan data, reduksi data, penyajian data, dan kesimpulan atau verifikasi.

\section{HASIL DAN PEMBAHASAN}

1. Peran Kepala Madrasah dalam Mengembangkan Sarana Pendidikan di MTs Negeri 2 Kota Cirebon

Berdasarkan

temuan penelitian, terdapat peran-peran kepala madrasah dalam mengembangkan sarana pendidikan. Dalam melaksanakan tugasnya sebagai pemimpin formal suatu lembaga pendidikan, kepala sekolah atau madrasah sedikitnya harus mampu berfungsi sebagai educator, manajer, administrator, supervisor, leader, inovator dan motivator. Selain itu, peran kepala sekolah terhadap kinerja tenaga kependidikan yaitu mendayagunakan tenaga kependidikan melalui 
kerjasama atau kooperatif, dimaksudkan bahwa dalam peningkatan profesionalisme tenaga kependidikan di sekolah. Kepala madrasah MTs Negeri 2 Kota Cirebon dalam melaksanakan perannya dengan berusaha pula mengkaitkan dengan tahapan-tahapan penyadaran, pengkapasitasan dan pendayaan agar terciptanya tujuan sekolah yang lebih baik.

Sesuai dengan yang dikemukakan oleh Mulyasa (2007, hlm. 103), terdapat tujuh peran utama kepala madrasah yaitu : kepala madrasah sebagai pendidik (educator), peran kepala madrasah sebagai pengelola (manajer), peran kepala madrasah sebagai administrasi (administrator), peran kepala madrasah sebagai pengawas (supervisor), peran kepala madrasah sebagai pemimpin (leader),peran kepala madrasah sebagai pembaharu (inovator) dan peran kepala madrasah sebagai pendorong (motivator). Peran-peran tersebut bertujuan untuk meningkatkan kualitas serta mengembangkan sarana pendidikan di lembaga pendidikan.

Berdasarkan hasil temuan penelitian menunjukan bahwa peran kepala madrasah sebagai pendidik (educator) dalam meningkatkan kinerja tenaga administrasi di MTs Negeri 2
Kota Cirebon sesuai dengan teori Mulyasa bahwa kepala madrasah harus memiliki strategi yang tepat untuk mengembangkan sarana pendidikan, menciptakan iklim yang kondusif, memberikan dorongan kepada seluruh tenaga pendidik dan kependidikan. Kepala madrasah menerapkan perannya sebagai pendidik (educator) dengan cara kepala madrasah selalu berusaha menjadi contoh dan berusaha selalu memberikan pengajaran tentang ilmu-ilmu yang beliau punya tentang pendidikan serta memberikan contoh yang baik kepada seluruh sumber daya manusia yang ada di madrasah dan berupaya membebaskan seluruh sumber daya ikut dalam pelatihan sebagai bentuk pengembangan ilmu dan untuk peningkatan profesionalisme dalam bekerja. Hal ini sesuai dengan yang dikemukakan oleh Mulyasa (2012, hlm. 98) dalam melaksanakan fungsinya sebagai educator, kepala madrasah harus memiliki strstegi ysng tepat untuk mengembangkan sarana pendidikan. Dalam melaksanakan perannya sebagai pengelola (manajer), kepala madrasah harus memiliki strategi yang tepat untuk mengembangkan sarana pendidikan melalui 
kerjasama atau koperatif, memberi kesempatan kepada seluruh sumber daya manusia dalam meningkatkan profesinya, dan mendorong keterlibatan seluh sumber daya manusia dalam berbagai kegiatan yang menunjang program madrasah (Mulyasa, 2010, hlm. 103). Selaras dengan kepala madrasah MTs Negeri 2 Kota Cirebon melaksanakan perannya sebagai pengelola (manajer) dengan cara beliau berusaha melaksanakan fungsi-fungsi manajer dengan membuat perecanaan tujuan, mengatur sumber daya manusia untuk pencapaian tujuan dengan selalu menekankan untuk berkerja sama dalam menyelesaikan tugas agar tercapainya tujuan madrasah. Menurut Andang (2013, hlm. 59) kepala madrasah bertangung jawab terhadap kelancaran pelaksanaan pendidikan dan pengajaran dilembaga pendidikan yang dipimpinnya. Peran kepala madrasah sebagai pengelola administrasi (administrator) yang dilaksanakan oleh kepala madrasah MTs Negeri 2 Kota Cirebon sesuai dengan teori yang di ungkapkan oleh Mulyasa bahwa Kepala sekolah sebagai administrator memiliki hubungan yang sangat erat dengan berbagai aktivitas pengelolaan administrasi yang bersifat

pencatatan, penyusunan dan pendokumenan seluruh program sekolah. Yang dilakukan oleh kepala madrasah MTs Negeri 2 Kota Cirebon sebagai pengelola administrasi (administator) dengan cara memberikan contoh dalam menyelesaikan tugas-tugas administrasi kepala madrasah serta memberi contoh kepada tenaga administrasi mengenai tugastugas tenaga administrasi (pencatatan, penyusunan, dan pendokumenan) dan mengikut sertakan tenaga administrasi dalam pelatihan administrasi khusus pendidikan atau sekolah.

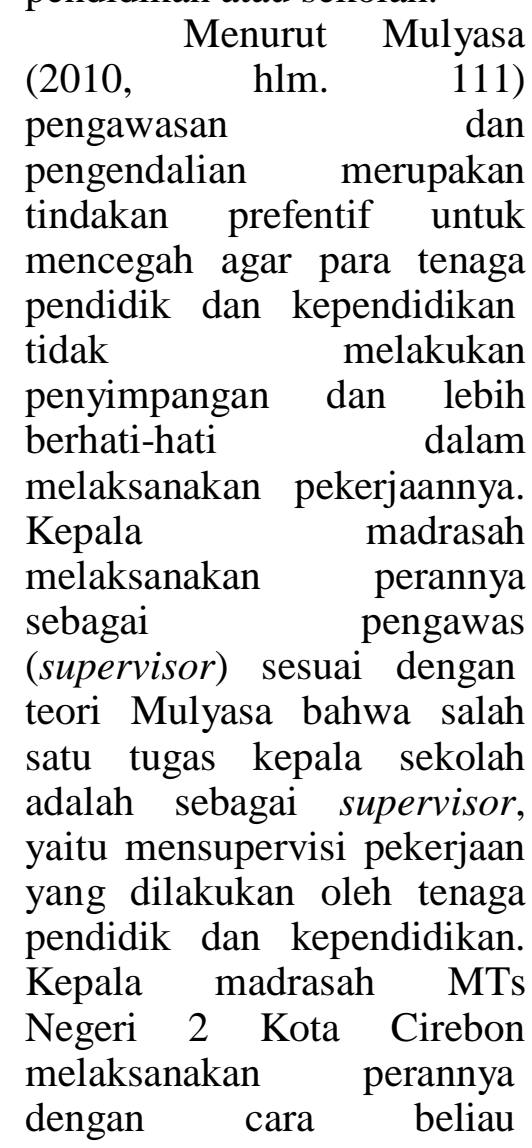


mengawasi kinerja para wakil kepala madrasah dan tenaga administrasi dan bila ada kesalahan dalam kinerja tenaga administrasi kepala madrasah menegurnya dan kemudian kepala madrasah membantu tenaga administrasi untuk menyelesaikan tugasnya dengan bertujuan agar dalam penyelesaian kinerja tenaga administrasi tepat waktu dan kemudian membuat tenaga administrasi meningkatkan kinerjanya.

$$
\text { Perannya sebagai }
$$
pemimpin (leader) sesuai dengan teori Mulyasa (2009, hlm. 112) bahwa kepala sekolah sebagai leader (pemimpin) harus mampu memberikan petunjuk dan pengawasan, meningkatkan kemampuan tenaga pendidik dan kependidikan. Kepala madrasah MTs Negeri 2 Kota Cirebon melaksanakan perannya sebagai pemimpin (leader) dengan cara mengawasi dan memberikan arahan kepada sumber daya manusia terutama kepada wakil kepala madrasah dan tenaga administrasi dalam menyelesaikan tugasnya agar semua proses pencapaian tujuan berjalan efektif dan efisien.

Peran kepala madrasah sebagai pembaharu (innovator) sesuai dengan teori Mulyasa (2009, hlm. 98), bahwa kepala sekolah sebagai innovator harus mampu mencari, menemukan, dan melaksanakan berbagai pembaharuan di sekolah. Dalam memimpin dan melaksanakan perannya sebagai pembaharu (innovator), kepala madrasah MTs Negeri 2 Kota Cirebon dengan bentuk perannya yaitu melakukan pembaharuan-pembaharuan dalam kepemimpinannya seperti, pembaharuan peraturan, kedisiplinan dan kebebasan dalam mengerjakan tugas dan pengembangan kemampuan khususnya kepada kepala madrasah dalam melalukan pengembangan sarana pendidikan yang ada di madrasah.

Peran kepala madrasah sebagai pendorong (motivator) yang dilaksanakan kepala madrasah MTs Negeri 2 Kota Cirebon sudah sesuai dengan teori Mulyasa (2012, hlm. 98) bahwa sebagai motivator kepala sekolah harus memiliki strategi yang tepat untuk meberikan motivasi kepada para tenaga pendidik dan kependidikan serta para siswa dalam melakukan berbagai tugas dan fungsinya. Kepala madrasah sebagai pendorong (motivator) yang dilaksanakan kepala madrasah MTs Negeri 2 Kota Cirebon, dengan cara memotivasi secara langsung tenaga pendidik dan kependidikan dalam 
menyelesaikan kerjanyanya serta berbagi ilmu pengetahuan yang kepala madrasah miliki kepada tenaga administrasi agar terciptanya peningkatan kinerja serta suasana kerja yang nyaman dan kondusif.

2. Strategi Kepala Sekolah dalam Mengembangkan Sarana Pendidikan di MTs Negeri 2 Kota Cirebon

Kepala madrasah merupakan pemimpin dalam suatu lembaga pendidikan Islam, yang tanpa adanya kepemimpinan kepala madrasah maka suatu lembaga pendidikan tidak berjalan sesuai dengan visi, misi dan tujuan madrasah yang telah di tetapkan. Suatu lembaga pendidikan tidak terlepas dari kinerja sumber daya manusia didalamnya sebagai penunjang berjalannya suatu proses tujuan. Dalam memimpin suatu lembaga pendidikan kepala madrasah dituntut memiliki strategi yang diterapkan oleh kepala madrasah sebagai pemimpin disuatu lembaga pendidikan untuk mencapai tujuan yang ditetapkan dengan mempertimbangkan

kekuatan, kelemahan, peluang, dan ancaman, yang dimiliki oleh sekolah tersebut.

Menurut Rohiat (2009 : 90) strategi yang dapat dilakukan oleh kepala madrasah dalam mengembangkan sarana pendidikan antara lain membentuk tim khusus, melaksanakan wrokshop atau pelatihan secara internal di sekolah, melakukan kerjasama dengan komite sekolah, melakukan kerjasama dengan lembaga atau instansi lain, dan melakukan kunjungan kesekolah lain. Selain itu khususnya dalam pengadaan sarana dan prasrana strategi yang dilakukan kepala madrasah antara lain melakukan kerjasama dengan LPTI atau perguruan tinggi, dan melakukan dengan kerjasama dengan dunia usaha atau industri. (Rohiat 2009 : 110)

Berdasarkan hasil temuan penelitian menujukan bahwa pembentukan tim khusus pengadaan sarana pendidikan dalam mengembangkan sarana pendidikan di MTs Negeri 2 Kota Cirebon sesuai dengan teori Rohiat (2009, hlm. 111), bahwa kepala madrasah harus memiliki strategi yang tepat untuk mengembangkan sarana pendidikan di madrasah yang dipimpinnya, memberikan kepercayaan kepada tim khusus pengadaan sarana pendidikan dalam melaksanakan tugasnya, memberikan suasana kerja yang kondusif dan efektif, dan memberikan nasehat serta dorongan kepada tim khusus pengadaan sarana pendidikan 
untuk melaksanakan tugasnya.

$\begin{array}{lr}\text { Strategi } & \text { kepala } \\ \text { madrasah } & \text { melakukan } \\ \text { workshop atau pelatihan } \\ \text { dalam } \\ \text { sarana pendidikan di MTs }\end{array}$

Negeri 2 Kota sudah sesuai dengan teori Rohiat (2009, hlm. 112), bahwa kepala madrasah harus memiliki strategi yang tepat untuk meningkatkan sarana pendidikan di madrasah. Kepala madrasah menerapkan strategi melaksanakan pelatihan atau workshop untuk pengadaan sarana prasrana, pemeliharaan sarana dan prasaran sampai dengan inventaris sarana dan prasarana pendidikan.

Strategi kepala madrasah bekerjasama dengan komite sekolah dalam mengembangkan sarana pendidikan di MTs Negeri 2 Kota Cirebon sesuai dengan teori Rohiat (2009, hlm. 113), bahwa kepala madrasah harus bekerjasama dengan komite sekolah untuk pemenuhan sarana dan prasarana pendidikan guna meningkatkan kualitas pembelajaran. Kepala sekolah menerapkan bekerjasama dengan komite dengan cara kepala madrasah mengikut sertakan komite sekolah dalam pengembangan sarana pendidikan.

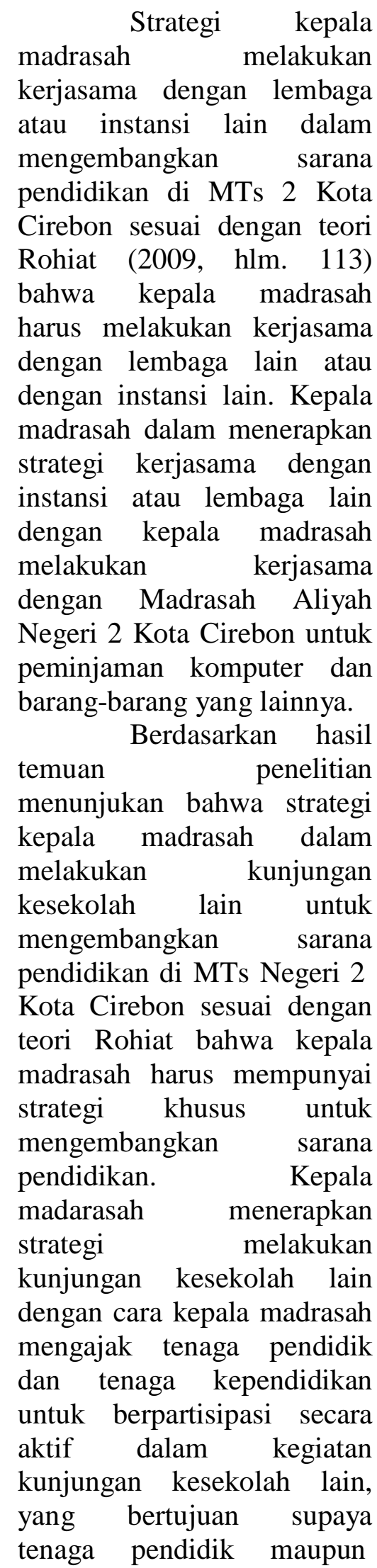


pendidikan bisa membandingan mutu pendidikan yang ada di MTs Negeri 2 Kota Cirebon dengan sekolah lain.

3. Faktor-faktor Penghambat dan Faktor Pendukung Kepala Madrasah dalam Mengembangkan Sarana Pendidikan di MTs Negeri 2 Kota Cirebon

a. Faktor Penghambat

Menurut Usaman

Husaini dalam Nawawi (2001, hlm. 27), mengembangkan sarana pendidikan merupakan tanggung jawab kepala madrasah, karena itu kepala madrasah harus menemukan faktor-faktor penghambat dan mencari solusi secara tepat untuk mengatasi hambatan yang muncul. Diantara faktor penghambat tersebut, (a) kurangnya perhatian pemerintah terhadap sekolah yang membutuhkan sarana dan prasarana, (b) lambatnya pencairan dana yang diberikan oleh pemerintah baik berupa dana BOS, maupun yang lainnya, (c) kurangnya motivasi kerja jika tugas itu tidak sesuai keinginannya, (d) pola pikir (mind set) sumber daya manusia yang sulit berubah atau menyesuaikan diri dengan tugas baru, dan (e) adanya tenaga yang orientasi kerjanya pada imbalan atau uang saja.

Selaras dengan uang dikemukakan Usmani Husaini Nawawi, kepala madrasah MTs Negiri 2 Kota Cirebon menemukan beberapa faktor yang menghambat pelaksanaan

pengembangan sarana pendidikan yaitu, kurangnya perhatian yang diberikan oleh pemerintah terhadap kebutuhan sarana pendidikan di madrasah yang belum optimal, lambatnya pencarian dana baik berupa dana BOS, maupun bantuan yang lainnya. Kepala madrasah juga menyadari bahwa dirinya kadang tidak berada di madrasah karena tugas di luar sekolah, beliau merasa kurang komunikasi yang membuat beda pemikiran dalam menyelesaikan masalah menjadi salah satu hambatan beliau yag sering terjadi. Serta penghambat yang sering terjadi adanya sumber daya manusia yang masih tidak mau berkembang atau meningkatkan kemampuannya.

b. Faktor Pendukung

Faktor pendukung pengembangan sarana pendidikan, tidak bisa dilepaskan dari 
keberhasilan kepala madrasah dalam melaksanakan perannya. Sumber daya manusia (SDM) sebagai individu dalam sebuah organisasi sangat menentukan keberhasilan organisasi tersebut dalam pencapaian tujuan. Menurut Shari Choudron yang dikutip oleh Sedarmayati (2012, hlm. 85), ada beberapa hal yang harus dilakukan untuk membentuk lingkungan yang mendukung program pengembangan sarana pendidikan antara lain works team and information sharing are building block, atau membentuk tim kerja komunikasi yang terbuka dengan pekerja, provide the training to do good job, atau pengembangan kemampuan dan keahlian suatu dimensi yang penting dalam program pengembangan, dan meningkatkan kualitas pendidikan yang ada di madrasah.

$$
\text { Selaras yang }
$$

dikemukakan oleh Shari Choudron yang dikutip oleh Sedarmayati mengenai faktor-faktor pendorong dalam mengembangkan sarana pendidikan, berdasarkan hasil penelitian peneliti yang sudah dilakukan melalui metode wawancara dan observasi kepada kepala madrasah dalam mengembangkan sarana pendidikan di MTs Negeri 2 Kota Cirebon menemukan beberapa faktor pendorong pelaksanaan pengembangan sarana pendidikan, pembagian kerja yang sesuai dengan tupoksi dan kemampuan sumber daya manusia, melakukan komunikasi dua arah terhadap seluruh sumber daya manusia, membebaskan sumber daya manusia yang ada di madrasah untuk terus melakukan pengembangan

kemampuan dengan cara mengikuti pelatihan baik yang diadakan di dalam madrasah maupun yang di adakan di luar madrasah, kepala madrasah juga melakukan supervisi dan memotivasi sumberdaya manusia agar dapat diberdayakan dengan baik sesuai tujuan madrasah, dan yang terakhir menurut kepala madrasah dengan cara mengatur sumber daya manusia sefleksibel mungkin agar dapat menyesuaikan keadaan apapun dalam pencapaian tujuan madrasah yang telah ditentukan.

\section{KESIMPULAN}




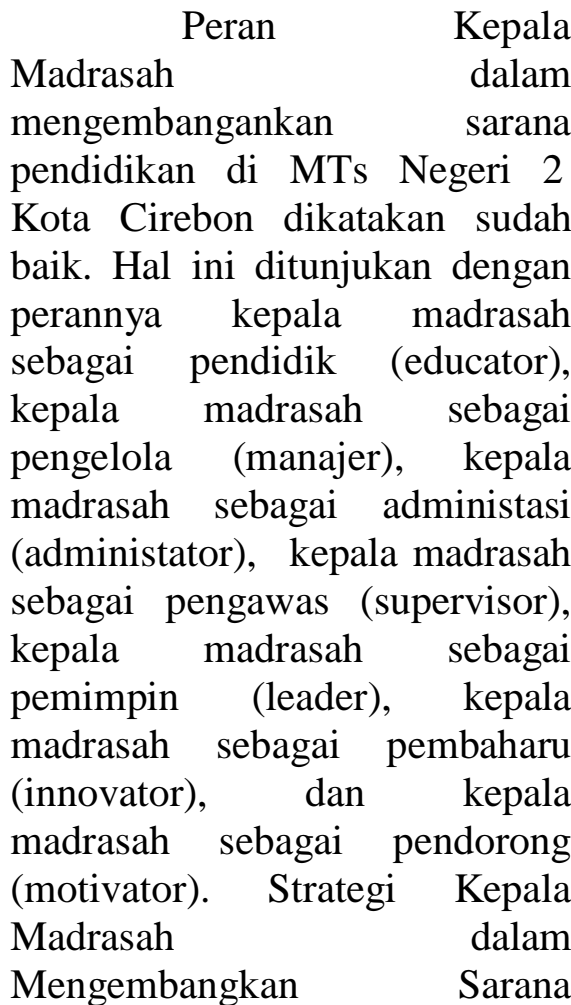

Pendidikan di MTs Negeri 2

Kota Cirebon dikatakan sudah baik. Hal ini ditunjukan dengan beberapa strategi yang dimiliki oleh kepala madrasah dalam mengembangkan sarana pendidikan, strategi tersebut yaitu membentuk tim khusus pengadaan sarana pendidikan, melakakukan wrokshop atau pelatihan, bekerjasama dengan komite sekolah, bekerjasama dengan instansi lain, dan melakukan kunjungan kesekolah lain. Faktor pendukung kepala madrasah dalam mengembangkan sarana pendidikan di MTs Negeri 2 Kota Cirebon yaitu untuk memberikan fasilitas yang terbaik untuk semua elemen yang ada di sekolah tersebut. Sedangkan faktor penghambat kepala sekolah dalam mengembangkan sarana pendidikan di MTs Negeri 2

Kota Cirebon yaitu kurangnya dana yang diberikan oleh pemerintah terhadap pihak sekolah, lamanya pencairan bantuan baik berupa dana maupun barang yang di berikan oleh pemerintah.

DAFTAR PUSTAKA

Afif, F dan Ismeth, A , 2010. Manajemen Strategik Keorganisasian Publik, Bandung: PT Refika Aditama.

Ambar, W.S, 2007. Manajemen Sarana dan Prasarana Pendidikan, Jakarta: CV Multi Karya Mulia.

At-Thayyib, 2012. Al-Qur'an dan Terjemah. Bekasi: Cipta Bagus Segara.

Bafadal, I, 2004.Manajemen Perlengkapan Sekolah, Jakarta : PT Bumi Aksara.

Dhiza Namira Fatihany, 2015. Dalam skripsi yang berjudul "Implementasi Rencana Strategi Sarana Prasarana di SMPN 5 Tanggerang Selatan”. Jakarta. Tersedia https://anzdoc.com//implement asi-rencana-strategi-saranaprasarana-di-smpn-5-tan.html.

Diakses pada Sabtu 1

Desember 2018 Pukul 09:00 WIB.

Diding, N dan Sibaweh, I, 2015.Pengelolaan Pendidikan, Jakarta : PT Raja Grafindo Persada

Fatah, N, 2015. Manajemen Strategik Barbasis Nilai, Bandung: PT Remeja Rosadakarya.

Fauzi, A, 2015.Manajemen Pendidikan Islam.Yogyakarta : K-Media 
Hajeng Dramastuti dan Karwanto, 2014.Dalam Jurnalnya yang

berjudul "Manajemen Sarana dan Prasarana dalam Upaya Peningkatan Kualitas

Pembelajaran Pada Jurusan Teknik Komputer dan Informatika di SMK Negeri2Surabaya".Surabaya.

Tersedia

https://jurnalmahasiswa.unesa. ac.id.Diakses Pada Sabtu 16 Februari 2019 Pada Pukul 20:30 WIB.

Kompri, 2014.Manajemen Sekolah Teori dan Praktek, Bandung: Alfabeta

$\begin{array}{rr}2015 . & \text { Manajemen } \\ \text { Pendidikan, } & \text { Bandung: }\end{array}$
Alfabeta.

Kurniadin, D dan Machali, I, 2012. Manajemen Pendidikan: Konsep \& Prinsip Pengelolaan Pendidikan, Jogjakarta: ArRuzz Media.

Kurniawan, A,2011.Manajemen Pendidikan di sekolah, Cirebon: Nurjati Press ,2017. Metodologi

Penelitian Pendidikan, Cirebon

: Eduvision

Matin, dan Fuad Nurhatati, 2017. Manajemen Sarana dan Prasarana Pendidikan: Konsep dan Aplikasi. Depok: PT Raja Grafindo Persada.

Minarti Sri, 2011. Manajemen Sekolah: Mengelola Lembaga Pendidikan Secara Mandiri. Yogyakarta: Ar-Ruzz Media.

Mulyasa, E, 2002. Manajemen Pendidikan Sekolah, Bandung : Remaja Rosda Karya.

Mulyasa, E, 2007. Manajemen dan Kepemimpinan Kepala
Sekolah, Jakarta : PT Bumi Aksara.

Kepemimpinan Kepala

Sekolah, Jakarta: Bumi Aksara 2011. Menjadi Kepala Sekolah Profesional. Bandung. PT Remaja Rosda Karya.

Musfah, J, 2015. Manajemen Pendidikan Teori, Kebijakan, dan Praktik. Jakarta : Prenada Media Group.

Nata, A, 2016. Pendidikan dalam Perspektif Al-Qur'an. Jakarta: Media Group. 